\title{
ASSESSMENT OF KNOWLEDGE, ATTITUDE AND PRACTICES AMONG MOTHERS REGARDING THE RECOGNITION, MANAGEMENT AND PREVENTION OF CHILDHOOD DIARRHOEA AND THE FACTORS INFLUENCING THEM
}

\author{
Apurva A. B1, Krishna Malagi', Sharanagouda Patil ${ }^{3}$ \\ ${ }^{1}$ Assistant Professor, Department of Paediatrics, MR Medical College, Kalaburagi. \\ ${ }^{2}$ Resident, Department of Paediatrics, MR Medical College, Kalaburagi. \\ 3 Professor and HOD, Department of Paediatrics, MR Medical College, Kalaburagi.
}

\section{BACKGROUND}

Diarrhoea remains a leading killer of children under 5, accounting for about 1.5 million deaths annually. The management of diarrhoea depends on the knowledge, attitude and practices of the mother which in turn are influenced by various social, cultural and demographic factors.

In this study, we aim to study these factors which determine the outcome of diarrhoeal illness.

\section{MATERIALS AND METHODS}

In this cross-sectional study, 200 mothers of under 5 children attending the outpatient and inpatient departments of Paediatrics at Basaveshwar Teaching and General Hospital (BTGH) and Sangameshwar Teaching and General Hospital (STGH) were interviewed with the help of a structured questionnaire. Data related to the knowledge regarding the diarrhoeal disease among mothers was studied. Social and demographic details of the mothers were collected and their influence on the attitude and practice in the management of diarrhoea was analysed.

\section{RESULTS}

$18 \%$ of the mothers could correctly identify the causes of diarrhoea and $65 \%$ believed that it could be prevented. Though $68.5 \%$ of mothers knew about ORS, the usage of ORS was just $6.5 \% .2 \%$ of the mothers knew the correct method of ORS preparation at home. The coverage of zinc was just $4.5 \%$ while fewer percentage of children received zinc for adequate duration. Literacy status of mother and father and the socioeconomic status were significantly associated with early health seeking behaviour, whereas knowledge about ORS was influenced by literacy status of mother and social economic status of the family.

\section{CONCLUSION}

The study reveals that, there exists a significant gap between knowledge of the mothers and the rightful practices in the management of childhood diarrhoea.

\section{KEYWORDS}

Diarrhoea, ORT, Zinc, Knowledge, Attitude, Practices.

HOW TO CITE THIS ARTICLE: Apurva AB, Malagi K, Patil S. Assessment of knowledge, attitude and practices among mothers regarding the recognition, management and prevention of childhood diarrhoea and the factors influencing them. J. Evolution Med. Dent. Sci. 2018;7(02):149-155, DOI: 10.14260/jemds/2018/33

\section{BACKGROUND}

Diarrhoea is the second leading cause of death in children under $5,{ }^{1}$ accounting for $9 \%$ of under 5 deaths. ${ }^{2}$ Approximately, $70 \%$ of these occur in first 2 years of life. ${ }^{3}$ Diarrhoea is also a leading cause of malnutrition in children under 5 years old. Though significant progress has been made in controlling this disease, the numbers still remain high with one child dying every 60 seconds, which is largely preventable. ${ }^{2}$ Diarrhoea is defined as the passage of 3 or more loose/liquid stools per day. ${ }^{1}$ The knowledge about the definition is important because frequent passing of formed stools/passing the loose, "pasty" stools by breastfed babies can be wrongly interpreted as diarrhoea.

'Financial or Other Competing Interest': None.

Submission 14-11-2017, Peer Review 20-12-2017,

Acceptance 27-12-2017, Published 08-01-2018.

Corresponding Author:

Dr. Apurva A. B,

Adarsh Nursing Home,

Opposite Ankal Petrol Pump,

Gunj, Kalaburagi-585104.

E-mail: apurvabinjawadgi@gmail.com

DOI: $10.14260 /$ jemds/2018/33
In India, the incidence of diarrhoea was found to vary between $14-20 \%$, the maximum risk being in between age group of 6-12 months. ${ }^{4}$

Oral rehydration therapy for the management of diarrhoea has been considered as one of the most important medical advances of $20^{\text {th }}$ century. The WHO/ UNICEF in 2004 released a joint statement recommending Zinc supplementation along with ORS for the management of childhood diarrhoea. ${ }^{5}$ Since then, low osmolarity ORS and Zinc have remained the cornerstone of management of diarrhoea.

In view of the disease burden, UNICEF rolled out a 7-point plan for comprehensive diarrhoea control which included treatment with low osmolarity ORS and Zinc and preventive measures that included measles and rotavirus vaccination, promotion of early and exclusive breastfeeding, vitamin A supplementation and promotion of hand washing with soap. ${ }^{6}$ Each of the above measures have the potential to significantly reduce the morbidity and mortality from diarrhoea, but the lack of their awareness and low practice rates continue to contribute to higher rates of incidence and mortality due to diarrhoea.

Despite of more than 40 years of promotion of ORS through all available channels, the knowledge of ORS among 
the community especially the mothers is just marginally satisfactory (46-72\%) as per various studies in India.7,8,9,10 Only 2 out of every 5 children with diarrhoea receive ORS and the difference in the coverage rate are even greatest between the richest and the poorest children. ${ }^{2}$

Recent study in India reveals the number of children receiving ORS and ORS with Zinc was $54.4 \%$ and $12.6 \%$ respectively. ${ }^{11}$ Adequate zinc supplementation for 10-14 days has been proven to reduce the incidence of diarrhoea by 14 $15 \%$ and mortality due to diarrhoeal illness by $23 \% .12$. Despite of its proven benefit and widespread promotion, the coverage of zinc globally was found to be less than $4 \% .^{2}$ The above statistics reflect the gap between the knowledge and practices prevailing in the community. Lower socioeconomic and literacy status of the mothers is known to be associated with less knowledge and usage of ORS among mothers. ${ }^{9}$ Diarrhoea is a disease of poverty with $60 \%$ of cases concentrated in 10 developing nations including India. ${ }^{13}$

Poor sanitation, lack of access to clean water and inadequate personal hygiene are responsible for about $88 \%$ of childhood diarrhoeal cases in India and up to $60 \%$ of diarrhoea related deaths globally.9,14

Exclusive breastfeeding is an important protective factor for reducing diarrhoeal morbidity and mortality. Nonbreastfed babies have an increased incidence of diarrhoea by $165 \%$ and are 10.5 times more likely to die from diarrhoea than breastfed babies. ${ }^{15,16}$

Hand washing with soap is found to be the most costeffective intervention, with decrease in the incidence of diarrhoea by $40 \% .{ }^{17}$ Studies have shown that washing hands with water alone is much less effective in preventing disease than using soap.

Proper sanitation is associated with decreased incidence of diarrhoea by $34 \% .18$

Over 1.1 billion people still practise open air defecation worldwide with India constituting half of such population. ${ }^{19}$

Vitamin A supplementation is known to reduce all causes of mortality by $24 \%$ and cases of diarrhoea by $15 \%$.

Scaling up of ORS coverage up to $100 \%$ wound prevent 93\% of diarrhoea related mortality. ${ }^{20 .}$

With so many variables influencing the incidence and outcome of diarrhoea, it is of utmost importance to take them into consideration while educating the public or framing national polices. In this study, we attempt to understand these factors which determine the outcome of diarrhoeal illness in children.

\section{MATERIALS AND METHODS}

This was a hospital-based cross-sectional study conducted at BTGH and STGH attached to MR Medical College, Kalaburagi, Karnataka, India over a period of 4 months (September 2016December 2016). The subjects recruited for the study were the mothers of children below the age of 5 years who attended the outpatient and inpatient departments of Paediatrics at BTGH and STGH. The mothers of the children who had at least one episode of diarrhoea in the previous 2 weeks were included in the study.

Keeping in view the diarrhoea incidence of $14.3 \%$ in the available literature, ${ }^{4}$ a sample size of 200 was estimated considering $95 \%$ confidence level with $5 \%$ relative error.

The study was approved by the Institutional Ethics committee, MR Medical College, Kalaburagi. The aim of the study was explained to the mothers and informed consent was taken. Confidentially of the participants was protected throughout the study.

A structured questionnaire was administered to gather information about the sociodemographic details, knowledge of the mothers regarding the cause, identification, assessment of diarrhoeal severity and the attitude and practices followed for its prevention and management. The questions framed were of multiple choice type and the mothers were followed to choose more than one option for few questions. The questionnaire was completed by an interview.

Socioeconomic status was determined using updated Kuppuswamy's socioeconomic scale (2014) which comprised of Education and occupation of the father and the per capita income of the family.

In this classification, class I is regarded as the highest order and class $\mathrm{V}$ being the lowest. The data collected was analysed. Mean, Standard Deviation and Percentages were calculated. The relation between the knowledge, attitude and practices with variables such as age of the mother, sex of the child, father's level of education, literacy status of the mother and socioeconomic status were analysed. Chi square test was used for the descriptive analysis. The $\mathrm{p}$ value of less than 0.05 was considered significant in this study. Analysis was done with the help of SPSS software - version 16.

\section{RESULTS}

A total of 200 mothers were interviewed over 4 months. Among the children of the mothers (study population) who were admitted, male children constituted $56.5 \%$ and females constituted $43.5 \%$. Majority of the mothers were in the age group of $21-25$ years (71.5\%). $43.5 \%$ of the mothers and $45 \%$ of fathers had secondary/higher secondary education. $78.5 \%$ of the mothers belonged to Hindu religion and $90.5 \%$ worked as housewives. Lower middle class (47.5\%) constituted the major socioeconomic class in our study. $54.5 \%$ of mothers were previously educated regarding diarrhoea, with mother's mother and mother-in-law being the main source of information followed by Health professionals. The demographic details of the mothers are presented in Table-1.

\begin{tabular}{|c|c|c|c|}
\hline & Variable & N & \% \\
\hline 1 & Sex of the child & & \\
\hline & a) Male & 113 & 56.5 \\
\hline & b) Female & 87 & 43.5 \\
\hline 2 & Age group of mother (in years) & & \\
\hline & a) <20 yrs. & 20 & 10 \\
\hline & b) 21-25 yrs. & 143 & 71.5 \\
\hline & c) 26-30 yrs. & 35 & 17.5 \\
\hline & d) >30 yrs. & 2 & 1 \\
\hline 3 & Literacy status of mothers & & \\
\hline & i) Primary schooling & 56 & 28 \\
\hline & $\begin{array}{l}\text { ii) Secondary/Higher secondary } \\
\text { schooling }\end{array}$ & 87 & 43.5 \\
\hline & iii) Diploma/graduate & 22 & 11 \\
\hline & iv) Illiterate & 35 & 17.5 \\
\hline 4 & Religion & & \\
\hline & i) Hindu & 157 & 78.5 \\
\hline & ii) Muslim & 42 & 21 \\
\hline & iii) Christian & 1 & 0.5 \\
\hline & iv) Others & - & - \\
\hline 5 & Socioeconomic status & - & - \\
\hline & i) Upper class & & \\
\hline
\end{tabular}




\begin{tabular}{|l|l|c|c|}
\hline & ii) Upper middle class & 46 & 23 \\
\hline & iii) Lower middle class & 95 & 47.5 \\
\hline & iv) Upper lower class & 48 & 24 \\
\hline & v) Lower class & 11 & 5.5 \\
\hline 6 & Father levels of education & & \\
\hline & 1) Primary schooling & 44 & 22 \\
\hline & $\begin{array}{l}\text { 2) Secondary/Higher secondary } \\
\text { schooling }\end{array}$ & 90 & 45 \\
\hline & 3) Diploma/graduate & 60 & 30 \\
\hline & 4) Illiterate & 6 & 3 \\
\hline $\begin{array}{l}\text { Table 1. Demographic and Social Characteristics of } \\
\text { Participants. Total Number of Participants = 200 }\end{array}$ \\
\hline
\end{tabular}

About knowledge regarding prevention of diarrhoea, $55.5 \%$ believed that diarrhoea could be prevented but only $55.38 \%$ of them knew at least one preventive measure. Regarding the cause of diarrhoea, majority of the mothers (39.5\%) identified teething as main cause for diarrhoea, while $18 \%$ answered that diarrhoea was caused due to consumption of contaminated food and water. $71.5 \%$ of mothers knew diarrhoea would lead to dehydration but $24.47 \%$ of them failed to identify any signs of dehydration. Majority (59.5\%) of the mothers would seek immediate medical care during an episode of diarrhoea while $13 \%$ waited to resolve on its own.

With respect to knowledge about ORS, a good number of mothers (68.5\%) had knowledge about ORS, whereas only $22.6 \%$ of them administered ORS to their children during the previous episode of diarrhoea. The number of children receiving adequate amount of ORS was much lower (16.1\%). Only $2 \%$ of the mothers, knew how to correctly prepare ORS at home.

Findings regarding feeding practices during diarrhoeal illness showed that $20 \%$ of mothers gave more feeds whereas food restriction was followed by $13.5 \%$ and $66.5 \%$ of mothers continued normal feeding. The reasons for feeding restriction included the misconception of gut rest and child not able to take orally. $82.4 \%$ of the mothers opted to continue breastfeeding during diarrhoeal episodes.

In issues related to Zinc administration, $4.5 \%$ of mothers administered ORS to their children. The proportion of children receiving Zinc for adequate duration was still lower $(1.5 \%)$. $78.9 \%$ of the mothers had exclusively breastfed their babies for 6 months.

The knowledge attitude and practices and represented is Table-2.

\begin{tabular}{|c|c|c|c|}
\hline 1 & Knows definition of diarrhoea & $\mathbf{N}$ & $\%$ \\
\hline & i) Correct definition & 82 & 41 \\
\hline & ii) Wrong response & 118 & 59 \\
\hline \multirow[t]{3}{*}{2} & Consider diarrhoea as a serious childhood illness & & \\
\hline & a) Yes & 128 & 64 \\
\hline & b) No & 72 & 36 \\
\hline \multirow[t]{3}{*}{3} & Know that diarrhoea is preventable & & \\
\hline & a) Yes & 130 & 65 \\
\hline & b) No & 70 & 35 \\
\hline \multirow[t]{3}{*}{4} & 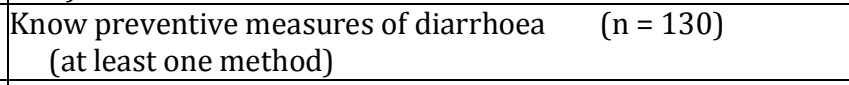 & & \\
\hline & a) Yes & 72 & 55.38 \\
\hline & b) No & 58 & 44.61 \\
\hline \multirow[t]{10}{*}{5} & Cause of diarrhoea (more than one response allowed) & & \\
\hline & a) Sudden exposure to heat/ sun & 26 & 13 \\
\hline & b) change in type of food and water & 72 & 36 \\
\hline & c) Evil eyes & 5 & 2.5 \\
\hline & d) Teething & 79 & 39.5 \\
\hline & e) Eating mud & 32 & 16 \\
\hline & f) Maternal diet & 7 & 3.5 \\
\hline & g) Weaning & 48 & 24 \\
\hline & h) Contaminated food and water & 36 & 18 \\
\hline & i) Do not know & 23 & 11.5 \\
\hline \multirow[t]{3}{*}{6} & Knows whether diarrhoea leads to dehydration & & \\
\hline & Yes & 143 & 71.5 \\
\hline & No & 57 & 28.5 \\
\hline \multirow[t]{5}{*}{7} & Able to identify signs of $(n=143)$ dehydration & & \\
\hline & a) When child has some dehydration & 100 & 69.93 \\
\hline & b) When child has severe dehydration & 7 & 4.86 \\
\hline & c) Only when child is in shock & 1 & 0.699 \\
\hline & d) Not able to identify any signs of dehydration & 35 & 24.47 \\
\hline \multirow[t]{6}{*}{8} & Usual response to diarrhoeal illness & & \\
\hline & a) Immediate medical care & 119 & 59.5 \\
\hline & b) Home care with herbal medication & 19 & 9.5 \\
\hline & c) Home care with ORS (standard ORS + Homemade ORS) & 13 & 6.5 \\
\hline & d) Home care with other Home available fluids & 23 & 11.5 \\
\hline & e) Wait to resolve on its own & 26 & 13 \\
\hline \multirow[t]{3}{*}{9} & Knowledge about ORS & & \\
\hline & a) Yes & 137 & 68.5 \\
\hline & b) No & 63 & 31.5 \\
\hline
\end{tabular}




\begin{tabular}{|c|c|c|c|}
\hline \multirow[t]{3}{*}{10} & $\begin{array}{l}\text { Whether ORS administered during previous episode of diarrhoea } \\
(\mathrm{n}=137)\end{array}$ & & \\
\hline & a) Yes & 31 & 22.6 \\
\hline & b) No & 106 & 77.4 \\
\hline \multirow[t]{3}{*}{11} & $\begin{array}{l}\text { Frequency and amount of ORS administration during previous episode } \\
\text { of diarrhoea }(n=31)\end{array}$ & & \\
\hline & a) Adequate & 5 & 16.1 \\
\hline & b) Inadequate & 26 & 83.9 \\
\hline \multirow[t]{4}{*}{12} & Know how to prepare ORS at home & & \\
\hline & a) Correct method & 4 & 2 \\
\hline & b) Incorrect method & 87 & 43.5 \\
\hline & c) Don't know to prepare & 109 & 54.5 \\
\hline \multirow[t]{4}{*}{13} & Feeding practices during episode of diarrhoea & & \\
\hline & a) Stop/reduced frequency & 27 & 13.5 \\
\hline & b) Continue normal feeding & 133 & 66.5 \\
\hline & c) Give more feeds & 40 & 20 \\
\hline \multirow[t]{3}{*}{14} & Continued breastfeeding during diarrhoea $(\leq 2$ yrs.) $(n=176)$ & & \\
\hline & a) Yes & 145 & 82.4 \\
\hline & b) No & 31 & 17.6 \\
\hline \multirow[t]{4}{*}{15} & Zinc administration during previous diarrhoeal episode & & \\
\hline & a) Yes & 9 & 4.5 \\
\hline & b) No & 127 & 63.5 \\
\hline & c) Don't know & 64 & 32 \\
\hline \multirow[t]{3}{*}{16} & Number of days for which zinc was administered & & \\
\hline & a) Adequate (10-14 days) & 3 & 1.5 \\
\hline & b) Inadequate & 6 & 3 \\
\hline \multirow[t]{3}{*}{17} & Practised exclusive breastfeeding for 6 months $(n=185)$ & & \\
\hline & a) Yes & 146 & 78.9 \\
\hline & b) No & 39 & 21.1 \\
\hline \multirow[t]{3}{*}{18} & Whether educated about diarrhoea & & \\
\hline & a) Yes & 109 & 54.5 \\
\hline & b) No & 91 & 45.5 \\
\hline \multirow[t]{5}{*}{19} & Source of information regarding diarrhoea $(n=109)$ & & \\
\hline & a) Mother/Mother-in-law & 52 & 47.7 \\
\hline & b) Relatives & 18 & 16.5 \\
\hline & c) Health professional & 34 & 31.1 \\
\hline & d) Hearsay & 5 & 4.6 \\
\hline
\end{tabular}

Table 3. Factors influencing the KAP of mothers in management of diarrhoeal illness

1) Response to diarrhoeal illness:

\begin{tabular}{|c|c|c|c|c|c|c|}
\hline & Individual variable & $\begin{array}{l}\text { Immediate } \\
\text { medical care }\end{array}$ & $\begin{array}{c}\text { Alternative } \\
\text { treatment }\end{array}$ & $\begin{array}{c}\text { Wait to resolve } \\
\text { on own }\end{array}$ & Total & $P$ value \\
\hline \multirow[t]{6}{*}{$\mathrm{A}$} & Age of mother (years) & & & & & \\
\hline & a) $<20$ yrs. & 8 & 10 & 2 & 20 & \\
\hline & b) 21-25 yrs. & 100 & 30 & 13 & 143 & \\
\hline & c) 26-30 yrs. & 10 & 13 & 9 & 32 & \\
\hline & d) $>30$ yrs. & 1 & 2 & 2 & 5 & \\
\hline & Total & 119 & 55 & 26 & 200 & 0.000097 \\
\hline \multirow[t]{6}{*}{$\mathrm{B}$} & Father's educational status & & & & & \\
\hline & a) Primary schooling & 12 & 16 & 16 & 44 & \\
\hline & $\begin{array}{l}\text { b) Secondary/Higher secondary } \\
\text { schooling }\end{array}$ & 57 & 28 & 5 & 90 & \\
\hline & c) Diploma/Graduate & 48 & 10 & 2 & 60 & \\
\hline & d) Illiterate & 2 & 1 & 3 & 6 & \\
\hline & Total & 119 & 55 & 26 & 200 & $<0.00001$ \\
\hline \multirow[t]{6}{*}{$\mathrm{C}$} & Literacy status of mother & & & & & \\
\hline & a) Primary schooling & 29 & 19 & 8 & 56 & \\
\hline & $\begin{array}{l}\text { b) Secondary/Higher secondary } \\
\text { schooling }\end{array}$ & 62 & 19 & 3 & 84 & \\
\hline & c) Diploma/Graduate & 21 & 3 & 1 & 25 & \\
\hline & d) Illiterate & 7 & 14 & 14 & 35 & \\
\hline & Total & 119 & 55 & 26 & 200 & $<0.00001$ \\
\hline $\mathrm{D}$ & Socioeconomic status & & & & & \\
\hline
\end{tabular}




\begin{tabular}{|c|l|c|c|c|c|c|}
\hline & a) Upper-class & 2 & 1 & 1 & 4 & \\
\hline & b) Upper middle class & 38 & 7 & 1 & 46 & \\
\hline & c) Lower middle class & 63 & 28 & 4 & 95 & \\
\hline & d) Upper lower class & 14 & 16 & 14 & 44 & \\
\hline & e) Lower class & 2 & 3 & 6 & 11 & \\
\hline & Total & $\mathbf{1 1 9}$ & $\mathbf{5 5}$ & $\mathbf{2 6}$ & $\mathbf{2 0 0}$ & $<0.00001$ \\
\hline
\end{tabular}

B) Literacy Status of Mother:

\begin{tabular}{|c|c|c|c|c|c|c|c|}
\hline & Individual variable & $\begin{array}{l}\text { Primary } \\
\text { schooling }\end{array}$ & $\begin{array}{l}\text { Secondary/ } \\
\text { Higher } \\
\text { secondary } \\
\text { schooling }\end{array}$ & $\begin{array}{l}\text { Diploma/ } \\
\text { Graduate }\end{array}$ & Illiterate & Total & P value \\
\hline \multirow[t]{5}{*}{$\mathrm{A}$} & Knowledge about cause diarrhoea & & & & & & \\
\hline & a) Correct response & 9 & 17 & 9 & 1 & 36 & \\
\hline & b) wrong response & 39 & 64 & 10 & 28 & 141 & \\
\hline & c) Does not know & 8 & 6 & 3 & 6 & 23 & \\
\hline & Total & 56 & 87 & 22 & 35 & 200 & 0.010583 \\
\hline \multirow[t]{4}{*}{$\mathrm{B}$} & $\begin{array}{l}\text { Whether diarrhoea leads to } \\
\text { dehydration }\end{array}$ & & & & & & \\
\hline & Yes & 35 & 73 & 21 & 14 & 143 & \\
\hline & No & 21 & 14 & 1 & 21 & 57 & \\
\hline & Total & 56 & 87 & 22 & 35 & 200 & $<0.00001$ \\
\hline \multirow[t]{5}{*}{$\mathrm{C}$} & Knowledge about ORS & & & & & & \\
\hline & Yes & 33 & 72 & 21 & 11 & 137 & \\
\hline & No & 23 & 15 & 1 & 24 & 63 & \\
\hline & Total & 56 & 87 & 22 & 35 & 200 & $<0.00001$ \\
\hline & Individual Variable & $\begin{array}{l}\text { Primary } \\
\text { schooling }\end{array}$ & $\begin{array}{c}\text { Secondary/ } \\
\text { Higher } \\
\text { secondary } \\
\text { schooling }\end{array}$ & $\begin{array}{l}\text { Diploma/ } \\
\text { Graduate }\end{array}$ & Illiterate & Total & $P$ value \\
\hline \multirow[t]{5}{*}{$\mathrm{D}$} & Feeding practices during diarrhoea & & & & & & \\
\hline & a) Stop/reduced feeding & 12 & 8 & 1 & 6 & 27 & \\
\hline & b) Continue normal feeding & 36 & 62 & 13 & 22 & 133 & \\
\hline & c) Increased feeding & 8 & 17 & 11 & 4 & 40 & \\
\hline & Total & 56 & 87 & 25 & 32 & 200 & 0.012217 \\
\hline
\end{tabular}

\begin{tabular}{|c|c|c|c|c|c|c|c|c|}
\hline Individual variable & \multicolumn{3}{|c|}{ Knowledge about ORS } & \multicolumn{3}{c|}{ Exclusive breastfeeding for 6 months } \\
\hline Socioeconomic status & Yes & No & Total & P value & Yes & No & Total & P value \\
\hline a) Upper-class & 1 & 1 & 2 & & 1 & 1 & 2 & \\
\hline b) Upper middle class & 44 & 2 & 46 & & 40 & 2 & 42 & \\
\hline c) Lower middle class & 72 & 21 & 93 & & 73 & 13 & 86 & \\
\hline d) Upper lower class & 17 & 31 & 48 & & 27 & 18 & 45 & \\
\hline e) Lower class & 3 & 8 & 11 & & 5 & 5 & 10 & \\
\hline Total & $\mathbf{1 3 7}$ & $\mathbf{6 3}$ & $\mathbf{2 0 0}$ & $\mathbf{< . 0 0 0 0 1}$ & $\mathbf{1 4 6}$ & $\mathbf{3 9}$ & $\mathbf{1 8 5}$ & $\mathbf{0 . 0 0 0 0 7}$ \\
\hline
\end{tabular}

\section{DISCUSSION}

The hospitals where the study was conducted, cater to a wide variety of population coming from diverse socioeconomic, cultural and educational background. Hence, we had the opportunity to study the population which at least in some part reflects the actual status of the society.

As mother is the primary caregiver in most of the circumstances, her awareness of the causes and knowledge of the management are critical in the reduction of diarrhoearelated morbidity and mortality.

$41 \%$ of the mothers among the study population knew the correct definition of diarrhoea which is similar to the values obtained from Rewa (50\%). ${ }^{21}$ and southern Odisha. 22

Only $64 \%$ of the mothers considered diarrhoea as a serious childhood illness which can explain the low medical care seeking behaviours $(59.5 \%)$ of the population. Study done by Sailesh Sutaria et $\mathrm{al}^{23}$ also showed that the proportion of mothers considering diarrhoea as a serious illness was low.
The health care seeking behaviours was low in our study as compared to national statistics. ${ }^{11}$

The findings of teething as a major cause of diarrhoea is in par with the study done by Kapoor et al and Priti Chaudhary et al. ${ }^{21}$

$11.5 \%$ of mothers relied upon available home foods for management of diarrhoea, the common foods being rice ganji and coconut water.

The knowledge about ORS in the mothers in our study (68.5\%) was in concurrence to the Sadasiba Padhy et al,22 S K Rasania et al and other Indian studies. 24

The usage rates of ORS were low $(22.6 \%)$ when compared to the proportion of mothers having knowledge about diarrhoea; the reasons cited by the mothers being, unawareness about the method of preparation and low acceptability of ORS by the children.

The usage rates of ORS in our study was similar to those found in NFHS-3 (26\%). ${ }^{9}$ 
The reason for lower ORS usage despite of higher medical care seeking behaviours could be due to fewer number of doctors prescribing ORS or failure on the part of doctors in effectively educating about the importance of ORS among mothers or absence of robust ORS promoting activities in the hospitals and the community.

The values regarding the adequacy of ORS treatment was further more disappointing in our study as only $16.1 \%$ of children treated with ORS received adequate amount of ORS during their illness.

Our study showed a lower rate of interruption/decreased feeding as compared in those found in NFHS-3 survey and other studies. ${ }^{10}$

The zinc usage in our study was substantially low with only $1.5 \%$ of children with diarrhoea receiving zinc for adequate duration which is similar to other Indian studies. 9,25

The rate of continued breastfeeding during diarrhoea in our study (82.4\%) was similar to that found in Chaudhary P et al's study. ${ }^{8}$

$78.9 \%$ of our mothers practised exclusive breastfeeding which is much higher than Indian standards (64.9\%) which is a welcome measure. ${ }^{26}$

$68.48 \%$ of the children were vaccinated against measles as compared to $78.99 \%$ found in Rapid survey on children study - 2013.11

The major source of diarrhoea-related information was mother/mother-in-law (47.7\%), followed by health care professional (31.1\%).

On statistical analysis, age of mother, father's educational status, literacy status of the mother and socioeconomic status of the family were significantly associated with response to diarrhoeal illness. Whereas literacy status of the mother was significantly associated with knowledge about diarrhoea, knowledge about ORS and rightful feeding practices during diarrhoea. (Table 3).

\section{CONCLUSION}

As mother is the primary caregiver in most of the circumstances, her awareness of the causes and knowledge of the management are critical in the reduction of diarrhoearelated morbidity and mortality.

Knowledge and practices should go hand in hand. Our study reveals a significant gap in the knowledge and practices of mothers in management of childhood diarrhoea. Though this gap may be somewhat compensated by higher rates of exclusive breastfeeding and vitamin A coverage rates, the importance of protective effect of exclusive breastfeeding, correct weaning practices, measles vaccination and vitamin $\mathrm{A}$ supplementation still needs to be stressed upon, which are cost effective and are proven interventions in decreasing diarrhoea-related morbidities and mortality.

Nonetheless, there is a stressed need for creating awareness about proper use of ORS and Zinc with due consideration to the cultural and social beliefs of the people.

\section{REFERENCES}

[1] Diarrheal disease. WHO. Media Centre. Factsheet. Updated 2017. http://www.who.int/mediacentre/factsheets/fs330/e n/ Last accessed on 19/08/2017.

[2] UNICEF. Committing to child survival: a promise renewed. Progress report 2013; p. 20.
[3] Walker CLF, Rudan I, Nair H, et al. Global burden of childhood diarrhea and pneumonia. Lancet 2013;381(9875):1405-16.

[4] United Nations Children's Fund and Ministry of Health and Family Welfare, Govt of India. 2009. Coverage evaluation survey. All India Report. New Delhi: UNICEF, 2010.

[5] WHO/UNICEF. Joint statement. Clinical management of acute diarrhea. 2004.

[6] UNICEF/ WHO. Diarrhoea: why children are still dying and what can be done. New York: 2009; p. 2.

[7] Rasania SK, Singh D, Pathi S, et al. Knowledge and attitude of mothers about oral rehydration solution in few urban slum of Delhi. Health and population perspectives and issues. 2005;28(2):100-7.

[8] Chaudhary P, Basu S, Dzeyie KA, et al. Knowledge, attitude and practice of mothers regarding Diarrhoeal illness in children under 5 years of age: a cross sectional study in an urban slum of Delhi, India. J Commun Dis 2014;46(3):13-21.

[9] International Institute for Population Sciences (IIPS) and Macro International. 2007. National Family Health Survey (NFHS-3), 2005-06: India: Vol 1. Mumbai: IIPS.

[10] Shah MS, Ahmad A, Khalique N, et al. Home based management of acute diarrhoeal disease in an urban slum of Aligarh, India. J Infect Dev Ctries 2012;6(2):137-42.

[11] Rapid survey on children 2013-2014, Ministry of Women and Child Development, Government of India.

[12] Walker CLF, Black RE. Zinc for the treatment of diarrhea: effect on diarrhea morbidity, mortality and incidence of future episodes. International Journal of Epidemiology 2010;39(suppl 1):i63-i9.

[13] Diarrhea and Pneumonia working group. Progress over a decade of zinc and ORS scale-up: Best practices and lessons learned. 2016; p. 4.

[14] Pruss-Ustun A, Bartram J, Clasen T, et al. Burden of disease from inadequate water, sanitation and hygiene in low and middle income settings: a retrospective analysis of data from 145 countries. Tropical Medicine and International Health 2014;19(8):894-905.

[15] Black RE, Allen LH, Bhutta ZA, et al. Maternal and child undernutrition: global and regional exposures and health consequences. Lancet 2008;371(9608):243-60.

[16] Bhutta ZA, Das JK, Walker N, et al. Interventions to address deaths from childhood pneumonia and diarrhoea equitably: what works and at what cost? Lancet 2013;381(9875):1417-29.

[17] Curtis V, Cairncross S. Effect of washing hands with soap on diarrhoea risk in the community: a systematic review. The Lancet Infectious Diseases 2003;3(5):27581.

[18] Waddington $\mathrm{H}$, Snilsviet B, White B, et al. Water, sanitation and hygiene interventions to combat childhood diarrhoea in developing countries. Synthetic Review No 1. New Delhi: International Initiative for Impact Evaluation 2009.

[19] WHO and UNICEF. Joint monitoring programme for water supply and sanitation, progress on drinking water and sanitation. 2012 update, New York: UNICEF, 2012. 
[20] Munos MK, Walker CLF, Black RE. The effect of oral rehydration solution and recommended home fluids on diarrhoea mortality. International Journal of Epidemology 2010;39(Suppl 1):i75-i87.

[21] Kapoor P, Rajput VJ. Maternal knowledge, attitudes and practices in diarrhoea. Indian Pediatr 1993;30(1):85-7.

[22] Padhy S, Sethi RK, Behera N. Mother's knowledge, attitude and practice regarding prevention and management of diarrhoea in children in Southern Odisha. Int J Contemp Pediatr 2017;4(3):966-71.

[23] Sutariya S. Talsania N, Shah C. Study of prevalence of diarrhoeal diseases amongst under five population. National Journal of Community Medicine 2011;2(1): 96-9.
[24] Shah D, Choudhury P, Gupta P, et al. Promoting appropriate management of diarrhoea: a systematic review of literature for advocacy and action. UNICEF PHFI series on newborn and child health, India. Indian Pediatr 2012;49(8):627-49.

[25] UNICEF. Management practices for childhood diarrhoea in India: survey of 10 districts, New Delhi: UNICEF, 2009.

[26] UNICEF. From the first hour of life: making the case for improved infant and young child feeding everywhere. UNICEF, New York, 2016. 